\title{
Invisible Women: Entrepreneurship, Innovation, and Family Firms in Nineteenth-Century France
}

B. ZORINA KHAN

\begin{abstract}
The French economy has been criticized for a lack of integration of women in business and for the prevalence of inefficient family firms. A sample drawn from patent and exhibition records is used to examine the role of women in enterprise and invention in France. Middle-class women were extensively engaged in entrepreneurship and innovation, and the empirical analysis indicates that their commercial efforts were significantly enhanced by association with family firms. Such formerly invisible achievements suggest a more productive role for familybased enterprises, as a means of incorporating relatively disadvantaged groups into the market economy as managers and entrepreneurs.
\end{abstract}

"This business model ... melds entrepreneurial passion with a long family tradition."

$\mathrm{T}$ he contributions of women to production and productivity, both within the household and in formal business organizations, crucially affect economic and social growth. Yet much of the relevant evidence is elusive, and women's entrepreneurial activities still remain largely invisible or contested. Some scholars argue that industrialization was driven by an "industrious revolution" during which women redirected

The Journal of Economic History, Vol. 76, No. 1 (March 2016). (C) The Economic History Association. All rights reserved. doi: 10.1017/S0022050716000449

B. Zorina Khan is Professor of Economics, Bowdoin College, 9700 College Station, Brunswick ME 04011 and Research Associate, NBER. E-mail: bkhan@bowdoin.edu.

This research benefited a great deal from the assistance and comments of Serge Bénoit, Esther Brubaker, Anne Chanteux, Christiane Demeulenaere-Douyère, Gérard Emptoz, Claudia Goldin, Liliane Hilaire-Pérez, Eric Hilt, Phil Hoffman, Philippe Honigman, Naomi Lamoreaux, Tom Nicholas, and Gilles Postel-Vinay. The paper was also significantly improved by the suggestions of Ann Carlos and two anonymous referees, as well as discussions during presentations at the National Bureau of Economic Research, Toulouse University, and the Association Française de Science Economique. Thanks are due to the very helpful staff at the Société pour l'encouragement de l'industrie nationale, the Institut national de propriété industrielle, the Archives nationales de France, the Bibliothèque nationale de France, and the Conservatoire national des arts et métiers. I am grateful for the support of the National Science Foundation, the Center for the Protection of Intellectual Property, the Hoover National Fellows Program and the IP2 Center at Stanford University. All language translations are my own. Liability for errors is limited to the author.

${ }^{1}$ See the firm's website: http://www.wendelgroup.com/fr/300-ans-dhistoire 16.html. James (2006) account of "family capitalism" highlights the role of women entrepreneurs in the early development of the Wendel business enterprise. 
their attention from household labour towards market production (de Vries 2003). By contrast, Claudia Goldin (1986) and Sara Horrell and Jane Humphries (1995) have suggested that in earlier stages of economic development women played a more central role, relative to their position under the increased specialization and division of labour by gender that characterized the advent of industrialization and Smithian economic growth. Cultural historians highlight social attitudes and legal norms that deprecated and reduced female participation in the market economy, with the corresponding retreat of urban middle-class women to a separate domestic sphere. ${ }^{2}$ In France, Janine Marie Lanza (2007, p. 230) similarly claims that the economic standing of women deterioriated after the French Revolution because guilds were no longer able to protect those widows who had inherited the skilled trades of their husbands. In addition, she identifies an "increased hostility toward women in the marketplace."

The prevalence of family firms among European enterprises is another contentious issue related to the role of women in business and the market economy. Prominent business historians (Landes 1969; Chandler 1994) contend that family firms tend to be inefficient modes of organizing economic activity in comparison to the impersonal modern corporation that is better able to take advantage of specialized management inputs and economies of scale. Such family-run enterprises (it is argued) are typically undercapitalized, deficient in risk-taking and managerial abilities, more concerned with the pursuit of personal utility than profit maximization, and characterized by suboptimal scale and scope. David Landes (1969, p. 528), for instance, claims that French business was "familyowned and operated, security-orientated rather than risk-taking, technologically conservative and economically inefficient." ${ }^{3}$ These problems are exacerbated at the time of a transfer of power from the original founder to family members who might be less adept or knowledgeable about internal and external factors in the firm and industry (Pérez-González 2006; Cucculelli and Micucci 2008; Nicholas 1999). ${ }^{4}$

Sheilagh Ogilvie $(2003,2004)$ argues that social capital, in the form of social norms, sanctions, and collective action, inhibited women from attaining their full potential in the marketplace, and also functioned as

\footnotetext{
${ }^{2}$ For related discussions, see Barker (2006), Crossick and Haupt (1995), Craig (2001), Crowston (2001), Thompson (2000), and Beachy, Craig, and Owens (2006).

${ }^{3}$ O'Brien and Keyder (2012, p. 125) conclude that "poverty of evidence does not seem to have inhibited controversy about the supposed entrepreneurial failure in French industry." Smith (2006) highlights the similarities between corporate enterprise in France and in other countries. See also Carter et al. (1976).

${ }^{4}$ Foreman-Peck, Boccaletti, and Nicholas (1998) studied 244 French businessmen and found a reduced likelihood of entrepreneurship associated with inherited wealth and having a father in business.
} 
mechanisms that excluded certain participants on the basis of such arbitrary criteria as class, race, gender, and ethnicity. Cultural and familybased norms, she concludes, were partly responsible for the uneven distribution of socioeconomic opportunities and outcomes by gender that have prevailed throughout history. The division of labour whereby men were paid in the marketplace and women predominantly contributed unpaid household work also had implications for business and entrepreneurship (Lachat 2014; Delphy and Leonard 1992; Hong 1990; Labardin 2008). If unearned income reduced the probability of female market activity, then the wives of successful entrepreneurs might not have acquired experience by participating in the family business, making them especially unprepared for taking over leadership roles in the event of death or incapacity of the male entrepreneur. ${ }^{5}$ Céline Bessière (2014) further states that women were subject to discrimination within their own families, and were not offered access to the skills and knowledge that would enable them to prosper at the head of the family firm (see also Wang 2010; Boudjaaba 2014). If cultural biases implied that women were restricted to petty trading or economic activities within the household, and to avoiding overt profit-maximization, their contributions were less likely to be at the frontier of entrepreneurship and innovation.

Such perspectives underestimate or ignore evidence that familybased enterprises can play a productive role by offering a conduit for the contributions of relatively disadvantaged groups, and allow women, in particular, to participate in the market economy as managers and entrepreneurs (James 2006). Family networks can compensate for lack of market access and high transactions costs, through the provision of patronage, reputation, trust, the ability to monitor group members more effectively, and by substituting the personhood of the firm for that of the individual. Relational contracts may result in stronger incentives to adhere to covenants, by means of private commitment devices to enforce and deter opportunism among participants. ${ }^{6}$ Family members might

\footnotetext{
${ }^{5}$ The rules for inheritance were governed by the Napoleonic code of 1804 (Vallier 1903). When a husband died and left a will, the division was determined by allocations based on the separate property of the wife, the separate property of the husband, and their "biens de communaute," or joint property. Wives had an inheritance right to part of the net community property, and all of their own separate property. Children gained the major part of the inheritance and succeeded to equal shares, regardless of their gender; widows were generally appointed guardians of their children, and entitled to the usufruct of the children's property. However, if the husband died intestate, relatives of any degree were given priority, and the widow received nothing.

${ }^{6}$ Lamoreaux (1996) argues that, rather than unproductive "tunneling," relational links in the banking sector were an effective means of mobilizing capital. Khan (2015) likewise finds that family ties were pervasive throughout all ranks of shareholders; family connections substituted for incomplete markets and helped to resolve problems that arise in the presence of such market imperfections as high risk and asymmetrical information, especially in new ventures.
} 
also have stronger allegiance than a hired employee to the survival of the enterprise and so be willing to bear greater variance in income, and smooth consumption over a longer time period. These family networks could provide "insider information" to identify and secure crucial inputs, and to reduce the risks inherent in entrepreneurship and innovation. Thus, a more positive interpretation of the prevalence of family firms highlights their role in attenuating agency and transactions costs, as well as bridging market imperfections that inhibit productivity growth and economic progress.

Amidst the plethora of studies of business organizations, little systematic historical research has focused on women in family firms, and the extent of their entrepreneurship and innovation in early industrialization. ${ }^{7}$ Part of the difficulty in addressing these critical questions lies in the "hidden" nature of women's economic activities. Their invisibility owes much to the legal, cultural, and familial norms that arguably relegated middle-class women to a "separate sphere," and to deficiencies in data that fail to capture certain facets of women's market activities. ${ }^{8}$ Case studies have noted the involvement of women in petty trades, such as seamstresses, tavern or boarding-house owners, and as producers of items consumed by other women. ${ }^{9}$ According to contemporaries (Watherston 1879 , p. 619), in mid-nineteenth-century France "female employment was mostly, if not entirely, in the inferior grades of industry, requiring little skill." 10 Quantitative studies are necessarily limited by existing evidence with the result that, as economic actors, women have a visible presence largely as unskilled workers in factories, as sole proprietors and petty producers, and to a lesser extent as passive investors in stock and bond markets.

This article contributes to our understanding of these questions by exploring the role of "enterprising" women in France during the first half

${ }^{7}$ Phillips (2006) and Martinetti (2013) find that family relationships served as effective mechanisms to transfer know-how, human capital, and financial resources within and across firms.

${ }^{8}$ Legal disabilities of women in the nineteenth century were especially burdensome in France (Bridel 1893; Desan and Merrick 2010; Beattie and Stevens 2013; Viret 2014).

${ }^{9}$ Angélique du Coudray, an innovative midwife, provides an intriguing earlier example of entrepreneurial abilities. She secured patents in 1759 and 1767 for a "machine" or anatomically correct doll to teach obstetric methods; in May 1756 the prestigious all-male Academy of Surgery examined her invention and formally acknowledged their approval. She was adept at securing patronage, and obtained a royal grant to travel the countryside to educate and train rural midwives, using her patented technology (Gelbart 1998).

${ }^{10}$ Grantham (2012) study of rural France found that women were typically involved in the farm work, but there was a low labour participation rate among the wives of merchants and tradesmen, and women in professional families. Grantham argues that middle-class women were subject to a gender-based division of labor, and avoided market pursuits as incompatible with their social status. 
of the nineteenth century. The analysis is based on a sample drawn from patent and exhibition records that sheds light on French women's innovation and enterprise and allows us to test the hypothesis that female entrepreneurial activities were related to participation in family firms. The results indicate that many middle-class women were engaged in allegedly nontraditional market activities, but such contributions were often invisible, in part because they were employed in family firms that were listed under the names of husbands or other relatives. ${ }^{11}$ Since a significant fraction of productivity growth is associated with technological innovation and the management of risk inherent in new products, untried processes, and emerging industries, the definition of entrepreneurship used here encompasses such factors. The discussion first addresses the laws and other institutions that enabled and constrained female inventive activity, entrepreneurship, and innovation. I then assess the extent of female technological innovation, and examine approximately one thousand patents of invention that were granted to women between 1791 and 1855. In the second half of the paper, I gauge women's contributions to commercialization and to managerial activities in innovative enterprises, by considering their participation in the Expositions publiques des produits de l'industrie française (hereafter the National Exposition of French Industry) and the Exposition universelle (Paris Universal Exposition). These data illuminate the characteristics of the numerous women who were active in managing and fostering growth in large, successful enterprises in nontraditional fields. Rather than retreating to a "separate sphere," women in these family firms worked in a context that productively combined household and nonhousehold activities. Together, the patent and exposition data offer unique insights into the role of family firms and the effects of such connections on women's entrepreneurship and innovation in the nineteenth century.

\section{INSTITUTIONS AND INNOVATION IN FRANCE}

Institutions, or the rules and standards that govern social and economic exchanges, may promote or inhibit the endeavours of all entrepreneurs. Although women have faced different constraints and opportunities

\footnotetext{
${ }^{11}$ Many such widows would have come from outside and "married into" the family firm, but it was not unusual for women in family firms to remain inside by marrying business partners, investors, or managers. In general, married women emerged from the "cover" imposed by the law and became visible only as widows. However, the patent and exhibitions data offer a unique opportunity to systematically observe women at all stages of the life/marital cycle. In particular, the exhibition records provide ample evidence of their participation in entrepreneurship and management before the death of related principals in the firm.
} 
than their male counterparts, some contemporary commentators seem to have overestimated the difficulties that female innovators faced in negotiating institutions such as the French patent system. ${ }^{12}$ French policies toward inventions and innovations developed from politically-oriented privileges that dated from the middle of the sixteenth century. By the eighteenth century, state policies towards innovation were based on an extensive, and overall somewhat arbitrary, network of rewards and incentives. Inventors and introducers and commercializers of inventions could benefit from titles, pensions that at times benefited extended parties including spouses and relatives, loans at minimal or zero interest, lump-sum grants, bounties or subsidies for production, exemptions from taxes, or monopoly grants in the form of exclusive privileges. Within this overlapping welter of initiatives, some women were able to exploit their personal influence and connections to gain access to valuable commercial rights, even without any formal contributions to the discovery or innovation. ${ }^{13}$ This convoluted network of state policies toward inventors and innovators was revised but not rationalized until 1844 .

Patentees in France could obtain a monopoly without any pretense at being the inventor and patents of importation could be obtained for the introduction of inventions from overseas. Patents were granted through a registration system, in which patent applications could not be refused as long as the fees were paid (Perpigna 1852; Blanc 1855; Renouard 1865; Galvez-Behar 2008). ${ }^{14}$ The 1791 statute (loi du 25 mai 1791) stipulated patent fees from 300 livres to 1,500 livres, based on the declared term of the patent. After the reforms of 1844, fees fell, ranging from 500 francs $(\$ 100)$ for a five-year patent, 1,000 francs for a ten-year patent, and 1,500 for a patent of 15 years, payable in annual installments. ${ }^{15}$ If the

\footnotetext{
${ }^{12}$ Daubié (1866) claims the French patent system was biased against women.

${ }^{13}$ Hilaire-Perez (2000, p. 30) refers to "La forte liaison qui existe en France au XVIIIe siècle entre technique et politique." As one of the referees points out, such connections brought unevenlydistributed advantages that enhanced the abilities of some women to participate in risk-taking and innovation, while serving as obstacles to the efforts of the less-privileged.

${ }^{14}$ The high fees comprised the only official filter for a French patent grant. When an application was made for a patent on an "invisible woman," Napoleon was apparently incensed on learning that he could not refuse to grant the patent, and ruled that all French patent grants should henceforth include a stipulation that the government did not guarantee such rights ("sans garantie du gouvernement"). Nevertheless, some women felt that the authorities were likely to refuse patents to female inventors, a perception that may have discouraged their applications. In the United States, a highly-developed market for inventions allowed impecunious inventors to mobilize capital, but in Europe the high fees, and lack of a seal of approval from a centralized examination system, resulted in lower access to property rights in inventions for both men and women (Khan 2000, 2005).

${ }^{15}$ Such reduced fees were still out of reach of the working class (Sicsic 1992).
} 
patent right were assigned (sold off) the total fees for the entire term of the patent had to be paid upfront. The uncertainties of patent rights that were not validated by prior examination were all the greater because of the monetary and other transactions costs that confronted anyone who wished to find out information about prior patents. ${ }^{16}$ For both buyer and seller, the legal and economic risks associated with a registration system likely reduced the net expected value of trade in the market for inventions (Khan 2005, 2013). ${ }^{17}$

The state was also involved in the discretionary promotion of invention and innovation through policies beyond the granting of patents. The inventor of a discovery of proven technical utility or usefulness in the marketplace could choose between a patent or making a gift of the invention to the nation in exchange for an award from funds that were set aside for the encouragement of industry. National institutions such as the Société d'encouragement pour l'industrie nationale were established to promote mercantilists ends, and emulated at both the regional and national levels (Redondi 1988). The Society consisted of eminent scientists and industrialists who awarded a number of medals each year to stimulate new discoveries in areas they considered to be worth pursuing, and also bestowed cash grants on inventors and manufacturers they deemed deserving. ${ }^{18}$ Committees often offered special commendation for innovations that promoted import substitution, or the replication of items that had been previously produced overseas. The award of assistance and pensions to inventors, innovators, and their families continued well into the nineteenth century.

${ }^{16}$ The Association of Inventors and Industrial Artisans was founded in 1849, and included numerous women, as well as husband and wife pairs, among its membership. The Association was especially concerned with improving access to information about patented inventions. Late in the nineteenth century patent lobbies were still protesting that the French law created disadvantages for inventors relative to other countries.

${ }^{17}$ The French system may be contrasted with the "democratic" orientation of American patent institutions, which were based on transparent rules, state-provided technical examinations of the invention, fees that were deliberately kept low to enable widespread access, and strong legal enforcement of property rights in patented inventions. In the United States, the patentee had to be the "first and true inventor" in the world, and patents could not be obtained even by employers. Once granted, the details about the specification of the invention were widely disseminated by the Patent Office, and also by private parties. Centralized examination, rapid diffusion of information, and strong legal enforcement facilated effective and pervasive markets in invention. For an extended discussion of comparative patent systems, see Khan $(2005,2013)$.

${ }^{18}$ Reports by industrial committees frequently gave out prizes for matching or duplicating the products of foreign producers, and for being successful in exporting to other countries. For instance, Mlle Manceau received awards from the Industrial Expositions and the Conservatory for Arts and Trades because her firm introduced in France a type of bonnet that was original to Italy. She was able to export the bonnets to other cities in Europe, the United States, and "remarkably" to Naples and Florence as well, possibly because of the lower price of her products. 
The transition from an Ancien Régime system of privileges to the innovation policies of the nineteenth century was personified by the Marquise d'Argence, who was adroit in exploiting all available avenues to gain support for her endeavours. As an appointed lacemaker to the royal court, she devised (or claimed credit for) a machine that could spin flax into very fine thread that was useful for making delicate lace. She employed a number of impoverished young women in a factory setting, ostensibly as a charitable project, to produce small amounts of thread that were then exhibited at expositions. The influential M. Molard, her representative before a committee of the Society for the Encouragement of National Industry, drew attention to her philanthropy, disabilities, and advanced age, and the recent death of her husband. Attempts by the committee to elicit information from the Marquise about the technical process itself, however, received the terse rejoinder, "It is my secret." 19 Despite noting that it was not clear whether hers was an economical method, the investigating committee still proceeded to include the requested notice on her behalf in the Society Bulletin, a prestigious achievement that undoubtedly boosted the market value of any invention receiving this honour. The Marquise obtained a patent for her invention in 1818, and patented an improvement the following year, but her charitable intentions did not extend to public diffusion of the specifications, and she again stipulated that the Patent Office should keep the information secret.

Wealthy men and women had additional advantages because they could use their financial resources and personal connections to attenuate other aspects of the law that might hinder commercialization. ${ }^{20}$ As in England and the United States, in nineteenth-century France a married woman was subject to the rules of coverture, which vested her legal rights in her husband, and contributed to her formal "invisibility." By law, her husband controlled any property she owned or acquired, as well as her earnings and wealth. Married women were prohibited from entering into contracts, could not be sued, and could trade on their own account only if authorized by their husband. Some husbands granted their wives greater freedom, and authorized them to conduct exchanges on their own accord. In exceptional circumstances, the courts formally allowed married

${ }^{19}$ Bulletin de la Société d'encouragement pour l'industrie nationale (SEIN) vol. 9, May 1819, pp. 139-41. Mme Gobert refused a gold medal for her improvements in varnish, because she similarly wanted to keep the process secret (p. 284.) One might question whether a poor and unconnected applicant would have possessed sufficient leverage to maintain such claims to secrecy.

${ }^{20}$ Rich families could, for instance, create legal trusts that protected the assets of wives and daughters. 
women to hold separate rights from their husbands, most commonly if it could be shown that her assets were at risk owing to his improvident behaviour. ${ }^{21}$ Courts were suspicious of such requests, however, because the revocation of coverture could lead to unscrupulous behaviour by debtors. Families could take unfair advantage of this separation of assets, by sheltering property from the just claims of creditors, and so limit or avoid their liability.

Many historians argue that such laws did not have much of an impact, and some even propose that they might have had a positive effect, because they caused women to become familiar with the legal system. ${ }^{22}$ However, research suggests that coverture in the United States affected women's economic activities negatively: legal reforms that removed such laws altered the economic costs and benefits associated with women's involvement in commercial activity, in a way that increased inventive activity by female patentees (Khan 1996, 2000). ${ }^{23}$ Married women's entrepreneurship in France was likely equally constrained by their legal disability under French law. Commercial exploitation of patented innovations depended on the right to contract, to produce the invented article, to assign or purchase patent rights, and to prosecute infringers. Investors and creditors would be less inclined to offer funding if they were uncertain about their ability to enforce their rights, leading to far greater capital imperfections for women relative to men. Widows and single women were de jure freed of these legal impediments but were unlikely to have had a standing that was de facto equal to men. ${ }^{24}$ The implications for women in business in France were sufficiently important that entire legal treatises were directed to the analysis of the law towards the wives of businessmen, including those who were active partners in the family firm (Bressoles 1888).

\footnotetext{
${ }^{21}$ See Hardwick $(1998,2009)$. A few of the patentees included information on their legal status as "sole traders," or "authorized by her husband," but it was possible that others were similarly circumstanced, so a systematic analysis of this variable is not possible.

${ }^{22}$ For instance, McMillan (2000) considers such laws to be toothless and merely "theoretical."

${ }^{23}$ Matilda Joslyn Gage (cited in Khan 2005, p. 161) observed: "How does the law recognize women? .. . It is only a little over a quarter of a century since the first state in this Union protected a married woman in the use of her own brain property. Is it any wonder then, that woman is not equal with man as an inventor?"

${ }^{24}$ Widows regained much of their legal automony on paper, and could also retain control of companies or property on their own account or as trustees on behalf of children who had not reached the age of majority. However, since there was always the possibility of remarriage, and marital status was not universally known, it might be expected that some aspects of legal disabilities likely still extended to widows, in practice. For instance, a creditor might be reluctant to make a loan to a woman, regardless of marital standing, because of the nonzero probability that she could become subject to coverture in the future. For studies of the law towards women in France, see Lanza (2007) and Desan and Merrick (2010).
} 
In the face of these obstacles, women entrepreneurs had to be prepared and able to take extra measures to enforce their rights. One example comes from patent litigation before the Civil Court of Paris to dispute the rights to a "very profitable invention." 25 In May 1850 Mme Rubigny obtained a 15-year patent for a process to preserve vegetables, by boiling with salt and aromatic herbs, and then drying them in the form of tablets, so they could be easily stored or transported, and then reconstituted. It is relevant to note that the patent document states she was a sole trader who was separated from her husband, and had legally filed to have independent economic rights ("séparée de corps et de biens d'avec son mari"). M. Masson's patent was granted in June 1850, one month later than Mme Rubigny's, but his invention was far more commercially successful. Chollet \& Company bought the rights to Masson's patent and sold the preserved vegetables in France and overseas, including the military and colonial markets. Mme Rubigny complained of infringement on several occasions, with countersuits by the Chollet firm. The legal tribunal ruled in favour of the larger company but noted that, since she had sold a modest amount of products, Rubigny should only pay 150 francs in damages plus costs. Rubigny appealed the judgement, but the final decision that came down in 1857 confirmed the ruling of the lower court.

In addition to patenting, women were investors in the financial sector, drawing on funds that were available to them as entrepreneurs, widows, or members of wealthy families. Philip Hoffman, Gilles Postel-Vinay, and Jean-Laurent Rosenthal $(1992,2001)$ find that women were frequent participants in credit markets in Paris, accounting for about 20 percent of transactions, but the majority of the market tended to feature trades by the upper income stratum, rather than artisans and ordinary workers. When investors established the Savings Bank and Provident Society of Reims in 1822, for a working class clientèle (farmhands, workers, artisans, and domestic workers; the investors were not allowed to benefit from its operation), 10 percent of the shareholders were women; several received income from businesses that their husbands had owned, while the rest were proprietors, merchants, and women of independent means. Ann Carlos and Larry Neal $(2004,2006)$ document comparable patterns among women shareholders in the Bank of England and in the London Share market, who seemed to be rather similar in their investment strategies to their male counterparts. Women thus participated readily in financial markets as providers of liquidity.

\footnotetext{
${ }^{25}$ The details of the testimony before the court are interesting, showing that Mme Rubigny was not cowed by the larger firm, and was spirited in asserting her rights to the invention.
} 
A key feature of entrepreneurship and innovation comprises the ability to manage uncertainty and to exploit the attendant risks to attain higher returns. Nineteenth-century France was subject to great political and economic turmoil, comprising a risky business environment for all, but particularly so for female entrepreneurs. French women faced institutional constraints that impinged on their economic activities, but there is ample evidence that, while they might have been inhibited, they were able to draw on sufficient entrepreneurial initiative and resources to engage in financial investments, as well as in industrial enterprise and innovation. I now explore the implications of their business involvement for our understanding of the role of family firms in economic development.

\section{PATENTING AND TECHNOLOGICAL INNOVATION}

Towards the end of the nineteenth century, Dr. Antoine de Neuville voiced the common view that French women did not have as much inventive faculty as did American women. ${ }^{26} \mathrm{He}$ also declared that the roster of mechanical patents filed by any woman in France was likely for inventions that had been devised by employees of her firm (1900, $\mathrm{p}$. 187): "There is no need to make mention here of patents for mechanical inventions, taken on behalf of the woman when she runs a trading house or factory or workshop. It is easy to see, in this case, the idea is due to a manager, a worker; ...Now, where we find the hand and mind of the woman herself is in the patented manufacturing of new corsets." Was de Neuville correct in his claim that French women were not inventive, and an unknown number of female patentees had obtained property rights in inventions that had been created by others? The examination of patent documents and the records of commercial expositions enable a more systematic empirical approach to the analysis of female inventors, innovators, and entrepreneurs in this period.

The patent laws in France allowed men and women to patent ideas that were the product of their employees or relatives. A husband or other family member might list a woman on the patent document in order to avoid legal controversies and probates in the event of his demise, but men might also legally patent an invention that was created by a woman. As such, patent statistics in the French case (as in any registration system with high fees) primarily provide an index of entrepreneurship and innovation, rather than inventive activity per se. In any event, what seems

\footnotetext{
${ }^{26}$ According to Voltaire (1829, p. 354), "women have been scientists and warriors, but there have never been any female inventors" (my translation).
} 
most striking about de Neuville's remarks is his implied assumption that female patenting and management of industrial enterprises were the norm. For, regardless of the truth of his claims, both the filing of patents and the ownership of firms testify to female entrepreneurial activities that are worth further examination.

Figure 1 shows the time series of patents that were obtained by women in France, relative to the national total. Between 1791 and 1855, French women obtained approximately one thousand patents. This total was far in excess of the 53 that their American counterparts were granted in the same period, despite the much lower fees and the streamlined application process in the United States. ${ }^{27}$ Women filed 2.4 percent of all French patents in this era, double the corresponding statistic for the United States even at the end of the century. The proportion of patents that was issued to women increased substantially after the legal reforms and cheaper patents of 1844, rising from 1.6 percent to 3.0 percent of the total in France. Figure 1 illustrates that the cyclical patterns of male and female patenting were similar, most notably declining after the political and economic turmoil associated with the "February Revolution" of 1848. At the same time, the patterns for female filing exhibit significantly lower variance over this period, and a two-sample F-test confirms the visual impression from the time series, suggesting that women who obtained these patents were partially insulated from the shocks that influenced upturns and downturns in male patenting.

Table 1 separates out patents by industry and occupation and confirms that the majority of women's patenting was in traditional fields such as household items, food, and apparel. Closer examination of other evidence indicates that many of these patents covered improvements that women themselves had devised. For instance, Mme Marie Breton, a Parisian midwife, obtained patents in 1824 and 1826 for a baby's feeding bottle and artificial nipples, for which she sought and obtained favourable notice from pharmacists and the Royal Academy of Medicine. A firm was established to manufacture and market her products, and she won numerous medals at exhibitions. Patents that women received for various types of hats, shoes, and corsets also increased over time. Women filed 57 patents

\footnotetext{
${ }^{27}$ French policymakers and commentators in the nineteenth century continually drew comparisons between the patenting experience in France and the United States. French reforms in the laws towards patents were in part influenced by the United States, and many observers in France were similarly impressed by the inventive abilities of American men and women, attributing their skills in part to the favourable legal and patent systems. Destable's (1899, p. 14) speech before the Appellate Court of Rouen compared the professional progress of women in France and the United States, to the detriment of French accomplishments, arguing that the "New World is the classical land of the new woman." See also Chanteux (2009) and Benoit et al. (2007).
} 


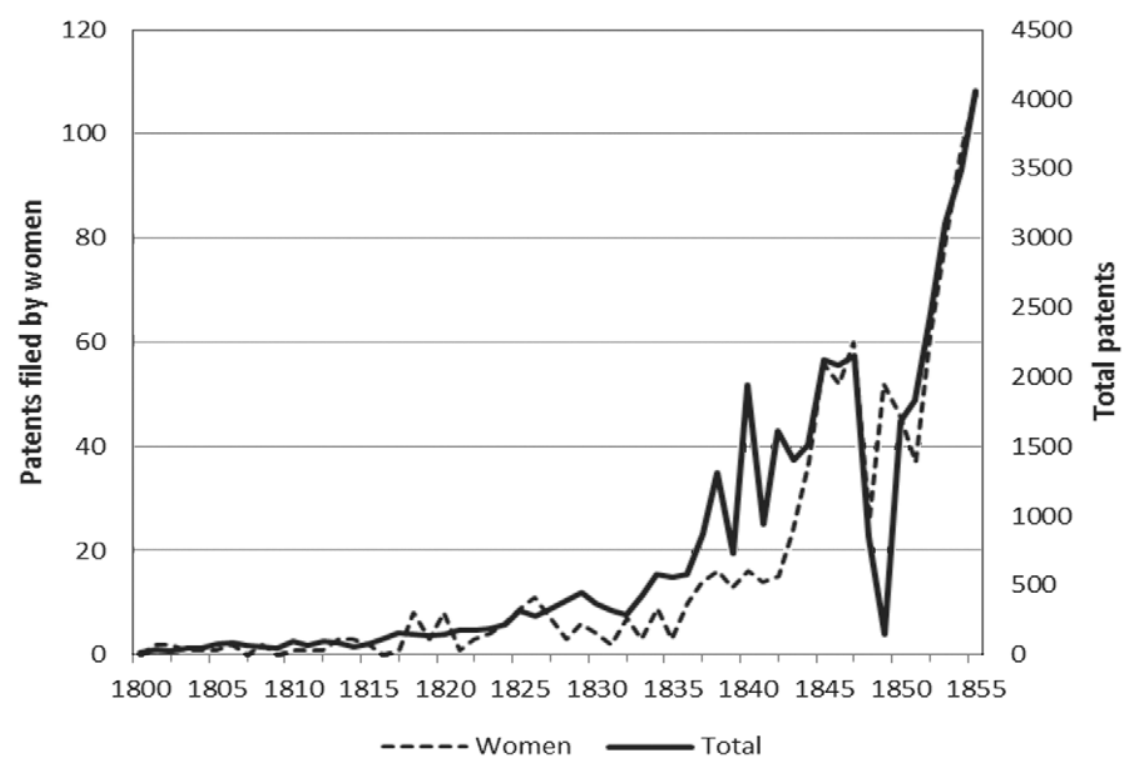

FIGURE 1

WOMEN INVENTORS AND TOTAL PATENTING IN FRANCE, 1800-1855

Sources: Institut national de propriété industrielle; France, Ministère de l'agriculture (various years); and Pasquale J. Federico (1964).

for corsets, comprising a disproportionately high 10.6 percent of all 538 corset inventions granted between 1791 and 1855 . The prominent textile industry attracted the same proportion of patents by men and women alike, although its relative importance in the patent records for women declines over time. As might be expected, men were much more likely to patent machines, engines, transportation inventions, and improvements in the iron and metal industries that required more technical experience and human capital.

The biographies of patentees who could be traced are obviously biased towards successful entrepreneurs but it is significant that, contrary to common perceptions, many of the women in this group were associated with innovative industrial enterprises. Amélie de Dietrich, a "maîtresse de forge" from a wealthy aristocratic background, was the owner of five patents for iron railroads and bridges that most likely covered inventions created by her workers. The Dietrich firm had been prominent in Alsace since the seventeenth century as producers of cast iron. Mme de Dietrich's husband died in 1806, leaving his 30-year old widow with a family firm that was in debt. She completely reorganized the enterprise, now called Veuve (widow) de Dietrich \& Fils, and shifted the focus of the product line to machine goods, stoves, bridges, and 
TABLE 1

CHARACTERISTICS OF PATENTING BY MALE AND FEMALE INVENTORS IN FRANCE, 1791-1855

\begin{tabular}{|c|c|c|c|c|}
\hline & \multicolumn{2}{|c|}{ Women } & \multicolumn{2}{|c|}{ Men } \\
\hline & Patents & Percent & Patents & Percent \\
\hline \multicolumn{5}{|l|}{ Industry } \\
\hline Agriculture & 17 & 1.7 & 17 & 1.5 \\
\hline Apparel & 190 & 19.1 & 71 & 6.3 \\
\hline Chemicals/medical & 120 & 12.0 & 83 & 7.3 \\
\hline Engines/machines/transport & 76 & 7.6 & 278 & 24.5 \\
\hline Food & 103 & 10.3 & 80 & 7.1 \\
\hline Household/building & 178 & 17.8 & 173 & 15.2 \\
\hline Iron/metals & 44 & 4.4 & 133 & 11.7 \\
\hline Printing/arts & 92 & 9.2 & 119 & 10.5 \\
\hline Textiles & 153 & 15.3 & 176 & 15.5 \\
\hline Miscellaneous & 27 & 2.7 & 5 & 0.4 \\
\hline \multicolumn{5}{|l|}{ Patent term } \\
\hline 5 years & 122 & 12.2 & 537 & 47.4 \\
\hline 10 & 46 & 4.6 & 227 & 20.0 \\
\hline 15 & 545 & 54.5 & 297 & 26.2 \\
\hline Addition & 288 & 28.8 & 73 & 6.4 \\
\hline \multicolumn{5}{|l|}{ Occupation } \\
\hline Professional & 68 & 18.0 & 198 & 24.3 \\
\hline Business(wo)man & 34 & 9.0 & 84 & 10.3 \\
\hline Manufacturer & 179 & 47.4 & 220 & 27.0 \\
\hline Corset-maker & 37 & 9.8 & - & - \\
\hline Teacher & 20 & 5.3 & 15 & 1.8 \\
\hline Artisan/worker & 40 & 10.6 & 156 & 18.9 \\
\hline Engineer/machinist & 1 & 0.0 & 142 & 17.4 \\
\hline \multicolumn{5}{|l|}{ Location } \\
\hline Paris & 789 & 78.8 & 562 & 51.3 \\
\hline Provinces & 167 & 16.7 & 437 & 39.9 \\
\hline Foreign & 45 & 4.5 & 96 & 8.8 \\
\hline
\end{tabular}

Notes: Patents were categorized into the industry of final use. Each patent was assigned to a single inventor, even if the rights were shared with collaborators. The data for women include all patents through 1855 , whereas the patents filed by men comprise a random sample drawn from the years 1791-1840.

Sources: INPI, and France, Ministère de l'agriculture (various years).

railroads. Regardless of whether the inventions were created by her or her workers, the patents indicate that the firm's production methods under her guidance were technologically innovative. The company expanded and acquired other factories, and Mme de Dietrich is credited with the introduction of decorative designs in industrial products. By the time of her death in 1855 , she left to her sons one of the most prominent 
enterprises in the region that would continue to flourish for another two centuries. $^{28}$

Women were present in the book industry, as booksellers, writers, printers, and publishers, comprising 10 percent of publishers and almost 25 percent of booksellers in 1850 (Arbour, 2003). Eugénie Niboyet (1796-1883), the granddaughter of physicist Lesage, who was an author and a notable figure in the struggle for women's rights, obtained an 1838 patent for indelible printing ink. Eulalie Lebel (1809-1898) provides another telling case study of the motivations and direction of female entrepreneurial efforts. ${ }^{29}$ She was the only daughter of Jacques-Auguste Lebel, a printer, and she married François-Marie Bouasse, an employee in a printing house. Her husband abandoned his wife and their two children, and she was responsible for paying his extensive debts. She founded her own printing house in 1845 , clearly drawing on skills and experience that had been gained within the family. Eulalie Bouasse's career in printing religious engravings and publishing, in association with her sons Henri and Emile, lasted until 1863. ${ }^{30}$ Between 1849 and 1855, Mme Bouasse-Lebel and Henri obtained four patents, related to making prints on different types of materials. Maison Bouasse-Lebel frequently entered their products at expositions, and received domestic and international accolades for their religious engravings, chromos, and albums. ${ }^{31}$

Patentees of items controlled by the French government, such as printing presses and firearms, had to be especially adept at maintaining quality and negotiating with state bureaucrats. The Gévelot company was

\footnotetext{
${ }^{28}$ The firm of Veuve Mermilliod and Son comprised yet another major family firm that employed more than a hundred workers, and lasted for more than a century. The widow and her three sons ran a cutlery manufacturing business, inherited from her husband, and Mme Mermilliod and her eldest son obtained a patent of addition for an 1842 system of knife-making machinery. The sons had complementary talents: Eugène, the co-patentee with his mother, was very innovative, whereas his brother Charles was an experienced manager, and several cousins also joined the firm. See Pagé (1898).

${ }^{29}$ Similarly, two patents were granted in 1854 and 1855 to the widow Berger-Levrault and her son, for ruling machines. Caroline Levrault took over the prestigious Maison Berger-Levraut, which still exists today, on the death of her husband, and successfully ran it for almost three decades, aided by her children and their spouses. On her death in 1850, her daughter Eleanor, widow of Pierre-Frédéric Berger, took over the business, and introduced new and modern metal presses. The company participated in the Universal Exhibition of 1855, and won medals several times at other events.

${ }^{30}$ The business relationship with her older son was not entirely amicable, highlighting some of the problems associated with family firms relative to impersonal corporations. For instance, he wanted to expand beyond the religious motif of their product line that was his mother's trademark. He left to form his own company in 1864, entering into competition with the firm that his brother Emile now headed.

${ }^{31}$ Maison Bouasse-Lebel received medals in London 1854, Paris 1855 and 1867, and also exhibited at the Centennial Exhibition in Philadelphia in 1876. Their engravings are highly-prized by collectors today.
} 
founded by Joseph-Marie Gévelot (1786-1843), who held two patents. When he died, his widow Joséphine and her teenage son Jules inherited the firm, which became world-famous for the quality of its firearms. They manufactured cartridges and fuses in their Paris location, and gunpowder at Issy, just outside the city. Joséphine Gévelot partnered with François Lemaire, a businessman, to obtain a patent for firearm cartridges in 1845 . Her company was associated with eight more patents in the following decade, including one for an invention from Italy. At the Paris exhibition of 1844, the jury awarded a bronze medal, noting that "Mme Veuve Gévelot has perfected the various details of manufacturing, and her products are always very much in demand in the market. The house of Gévelot produced well in 1839 [before her husband's death]; it produces a great deal better in 1844." ${ }^{32}$

The patent records signal growing sophistication over time among women at both invention and innovation. As the patent term shows, the majority of male patentees obtained patents that were shorter than the full term of 15 years; however, the average term was significantly different for women's patents. ${ }^{33}$ In the period before 1835, half of the patents that women filed were short five-year instruments, which were cheaper, and less risky investments if the applicant were uncertain about the value of the invention. However, over time that pattern changed significantly, towards full-term patents, and additions that incorporated improvements to the original invention. This shift was in part due to a closer correspondence between such higher-quality patents and women's participation in firms. The fraction of patents to women in noncommercial occupations such as midwives or teachers fell from 43.2 percent before 1835 , to 13.4 percent after 1850. Instead, patents were much more likely to be issued to women in manufacturing, which increased markedly over time, to almost two-thirds of all filings. Entrepreneurship requires flexibility to meet new opportunities, and this characteristic can be observed in several women inventors. For instance, the Joly sisters obtained a full-term patent on corsets, and listed themselves as corset-makers in 1848; however, by 1853 the sisters were manufacturing envelopes that were secure enough to use for confidential business transactions, for which they had obtained another patent.

\footnotetext{
${ }^{32}$ See Rapport du Jury central (1844, p. 607.)

${ }^{33}$ The term comprised a maximum duration, since the patent rights were lost if the patentee failed to maintain the annual payments. Overly optimistic patentees found it was wiser to let the patent right lapse before the end of the term. Mlle Elisa Caroline Edwards from Rouen took out a patent of 15 years in 1836, for catching fish, but she let it expire three years later. Similarly, M. Lize and his wife let their patent of five years for designing carpets lapse after two years, when they failed to pay up the required annual fee.
} 
Women may have been underrepresented in managerial and entrepreneurial positions in family firms because of a lack of training from their fathers. It is impossible to directly test this hypothesis with these data, but there are several examples of daughters who were clearly influenced by their fathers. ${ }^{34}$ The patent records provide useful examples of the likely influence of parents on the entrepreneurial tendencies of their daughters. Rosa Martres's patent documents noted that she was the daughter of the famous Antoine Gazy-Cazalat, a physicist, engineer, and inventor with some 44 patents to his credit through 1855. Mme Martres herself received seven patents for improvements in coffee makers, an extremely popular subject for inventors of the day. ${ }^{35}$ The Houels, mother and daughter, provide insights into the relationship between entrepreneurial mothers and their daughters. Mme Houel received a favourable citation from the jury at the 1823 exposition, for making paints that dried quickly, did not have a strong smell, and could be used on a wide array of materials ranging from wood to metal. In 1839, her daughter exhibited improvements on this paint, which led the jury to grant her a bronze medal.

In short, women might not have had significant exposure to machine trades and training (only one declared herself to be a "mécanicienne"), but they were still able to engage in industrial management and entrepreneurship, drawing on experience they had obtained in collaboration with parents, siblings, or husbands. ${ }^{36}$ Part of the credit for their success in running family firms undoubtedly was owed to the loyalty of their skilled employees. ${ }^{37}$ Female participation within family enterprises also allowed them to engage in transactions that would have been less likely in the marketplace, and to bypass the gender-biased

\footnotetext{
${ }^{34}$ The direction of influence may have also run in part from daughters to fathers. For instance, Richards (2010) found that legislators with only daughters in their household were more likely to vote in favour of women's economic rights.

${ }^{35}$ Mme Vassieux, another women inventor, was one of the most successful of the patentees in this area, and her coffee maker design was still being used and adapted many decades after the expiration of her six patents from the 1840s. A young male relative helped to market her products in other European countries. The Cheradame father and daughter provide another example of patenting running in the family. Antoine Cheradame received some six patents between 1828 and 1837, primarily for inventions to increase the brightness of lamps while maintaining their costs. His daughter Pauline obtained her first patent in 1846, and subsequently filed some nine patents for inventions in the following decade, mainly for making artificial flowers.

${ }^{36}$ Mme Carpentier, a producer of lace, collaborated with her sister's firm, and employed female business representatives in many towns and even internationally. She trained a young worker, Esther Joas, to be her assistant, and Mlle Joas herself became a prominent manufacturer and entrepreneur.

${ }^{37}$ The firm of Debuchy was notable for the quality of its workforce of almost 300 workers. The foreman, Auguste Flaveau, worked for the company from 1824 for more than three decades and himself received an award for his productivity.
} 
laws of property and contract that restricted their activities beyond the household. ${ }^{38}$

The number of patents per person provides an indicator of greater investments in inventive/innovative capital and professionalism in patenting activity. The patterns for multiple patenting in Table 2 are significantly different across countries, and these results are especially informative. In the United States two-thirds of women's patents were to inventors who never filed a second patent, whereas almost three-quarters of French patents (including improvements) were for multiple patents. For instance, Sophie-Geneviève Mercier obtained 15 patents between 1842 and 1855, the majority for various inventions to treat laundry, and two for cleaning cutlery, which required familiarity with chemical processing. Given the nontrivial patent fees, these inventions were likely to have been commercially successful, but Mercier comprises one of the "invisible women" about whom no further sources are available to illuminate her contributions to technological innovation and enterprise.

Early technology markets in the United States were extensive and well developed relative to other countries and created incentives for specialization and professional patenting. ${ }^{39}$ The significantly higher rates of professional patenting by women in France relative to the United States raise questions about the compensating mechanisms that accounted for this result. The overall patterns for female patentees indicate that professional patenting was associated with greater ownership of manufacturing companies and other related businesses. Women were active on both sides of the market for patent rights, as buyers and sellers, and as recipients of titles on behalf of their firms. For instance, the 300-year old firm of Wendel in the Moselle region of France has been regarded as an icon of French-style "family capitalism," expanding in the nineteenth century to become one of the industrial leaders in the European iron and steel industry (James 2006). The matriarch of the family business, Joséphine de Wendel (1784-1872), listed her occupation as "iron-works proprietor" when she obtained patents in 1839, 1847, and 1851, for improvements in coke-fired blast furnaces and iron products that were likely devised by

\footnotetext{
${ }^{38}$ Mme Veuve Désirée Debuchy inherited a large-scale prosperous textile-making enterprise in Tourcoing (Nord), which under the ownership of her husband, won medals each year from 1827 up to the time of his death. Under her management, the juries at the 1849 and 1855 exhibitions rewarded the products' good taste, low prices, their commercial success, and their competitiveness with English goods. (Rapports du jury mixte international (1855, p. 321)). The sons continued the tradition of earning awards for the excellence and affordability of its products, until the company was dissolved in 1886 .

${ }^{39}$ See Lamoreaux and Sokoloff (2001), Khan (2013), Pretel and Saiz (2012), Khan and Sokoloff $(1993,2004)$.
} 
TABLE 2

PATENTING BY FRENCH AND AMERICAN WOMEN INVENTORS IN THE NINETEENTH CENTURY

\begin{tabular}{|c|c|c|c|c|}
\hline & \multicolumn{2}{|c|}{$\begin{array}{l}\text { Patents by French Women } \\
\qquad(1791-1855)\end{array}$} & \multicolumn{2}{|c|}{$\begin{array}{c}\text { Patents by U.S. Women } \\
\quad(1790-1895)\end{array}$} \\
\hline & Patents & Percent & Patents & Percent \\
\hline \multicolumn{5}{|l|}{ Multiple patenting } \\
\hline One patent filed & 368 & 36.8 & 2,683 & 66.6 \\
\hline Two or three & 346 & 34.6 & 874 & 21.7 \\
\hline Four to nine & 227 & 22.7 & 324 & 8.0 \\
\hline Ten or more & 60 & 5.6 & 149 & 3.7 \\
\hline \multicolumn{5}{|l|}{ Coinventors } \\
\hline Female, related & 20 & 7.8 & 19 & 6.0 \\
\hline Male, related & 99 & 38.8 & 115 & 36.3 \\
\hline Female, unrelated & 36 & 14.1 & 35 & 11.0 \\
\hline Male, unrelated & 100 & 39.2 & 148 & 46.7 \\
\hline \multicolumn{5}{|l|}{ Marital status } \\
\hline Single & 296 & 29.6 & 127 & 21.2 \\
\hline Married & 414 & 41.4 & 240 & 40.0 \\
\hline Widowed & 290 & 29.0 & 233 & 38.8 \\
\hline
\end{tabular}

Notes: The data for French women include all patents through 1855, whereas the patents filed by U.S. women cover the years 1790-1895. Coinventors' relationships were determined by whether the individuals had the same surname, which will tend to be an underestimate. Each patent/award was assigned to a single inventor, even if the rights were shared with collaborators. The number of patents per person were underestimated for later cohorts.

Sources: INPI, and France, Ministère de l'agriculture (various years). United States Patent Office (various years).

her employees. The company maintained its position by keeping up with technological innovations, both from its own improvements and from overseas, including the importation of skilled workers from England who could reveal the latest industrial techniques. ${ }^{40}$

The grant of a patent often led to the establishment of new factories or firms to commercialize the invention or product. ${ }^{41}$ For example, a machine patent was granted to Mlle Gervais in 1834, and the same year a company was floated to exploit her inventions, in partnership with M. Raynal, a

${ }^{40}$ For a similar example, see Mme la Marquise de Raincourt (1776-1864), propriétaire des forges de Fallon (Haute-Saône), who obtained a patent in 1842 for an iron furnace, with a term of five years. The agent for the patent application was LeGrand, the manager of the forge.

${ }^{41}$ Mme Marie Larguier's application for a ten-year patent for the refining of suphur in match production lists her occupation as "manufacturer of matches." She and her husband founded a workshop in the neighbouring town of Clermont-Ferrand to manufacture the "chemical matches" that she had patented. 
rentier. Mlle Caroline-Françoise Lukkow assigned the rights to her orthopedic corset invention even before the patent was granted, to Auguste Daubian, a medical doctor, indicating a strong belief in the commercial value of the improvement. However, the majority of assignment contracts that could be traced involved married or widowed parties. M. Guicheux's patent of 1836 was assigned jointly to the Guérins (husband and wife), who formed a partnership limited by shares to exploit the patent, under the name of Guérin, femme Guérin et compagnie. The notarial records in 1851 also include the unhappy example of the patentee Joseph Barbier and his wife (a rentière) whose company was dissolved after their marriage broke up. ${ }^{42}$

Innovative women were prepared to defend their business interests to the fullest extent, whether as assignees or against them. Mme AnneCharlotte Matelin assigned her 1836 patent to M. Brisset with the stipulation that he should not reassign it to any other party, and also required that his improvement patent had to be taken out in her name. Mme Mougniard was a manufacturer of candles made of spermaceti mixed with wax, who purchased the full assignment rights to a patent for candle making that Heinrich Danker had filed in 1822. She entered into litigation with M. Chapelle for infringement of her patent, and also indicted Danker for not enforcing her rights as the exclusive assignee, requesting all possible legal remedies, including damages, an injunction, and confiscation of the allegedly infringing products. Chapelle countered that Mme Mougniard had unfairly tarnished his reputation and paralyzed his business, through notices she had advertised in the newspapers, the seizure of his goods, and her prosecution in the courts. He further charged that the patent was invalid, and requested that the court overturn her assignment, with compensation for his losses. These legal proceedings make it quite clear that she was acting on her own account and protecting her own interests.

The regressions in Table 3 investigate the determinants of the degree of professional patenting, as a proxy for greater investments in technological innovation. The results confirm that greater numbers of patents by women were linked to the ownership of manufacturing firms. Total patents per patentee were higher in the commercial center of Paris. The numbers of patents were not significantly related to the industrial sector, although the miscellaneous sector was less likely than the "nontraditional" fields to be associated with higher numbers of patents. As might be expected, "petty" inventions protected with five-year terms were negatively related to professional patenting. Perhaps the most intriguing results from the regression are related to marital status. The dummy variables represent

\footnotetext{
${ }^{42}$ See Fonds : MC Cote : ET/LXXXV/185103-r25, Numéro : 43053; Objet : dissolution de société d'exploitation de brevet de freinage des wagons.
} 
TABLE 3

BINOMIAL REGRESSIONS OF PATENTING BY FRENCH WOMEN, 1791-1855 DEPENDENT VARIABLE: NUMBER OF PATENTS PER PERSON

\begin{tabular}{|c|c|c|c|c|}
\hline & Coeff. & Wald Chi-sq & Coeff. & Wald Chi-sq \\
\hline Intercept & 10.2618 & $3.19^{*}$ & -11.4356 & $4.09^{* * *}$ \\
\hline Paris residence & 0.4021 & $34.09 * * *$ & 0.4312 & $39.23 * * *$ \\
\hline Year & 0.0061 & $3.88 * *$ & 0.0068 & $4.97 * *$ \\
\hline Mfg enterprise & -0.1171 & 0.83 & -0.0202 & 0.03 \\
\hline Mfg enterprise owned by wife/widow & 0.9489 & $41.26^{* * *}$ & 0.7026 & $22.03 * * *$ \\
\hline Wife/widow & -0.3649 & $34.31 * * *$ & -0.3223 & $26.96 * * *$ \\
\hline Five-year patent & -0.4940 & $23.02 * * *$ & -0.4228 & $17.2 * * *$ \\
\hline Industry & & & & \\
\hline Apparel & & & 0.0851 & 1.0 \\
\hline Food & & & -0.1199 & 1.36 \\
\hline Household & & & -0.0375 & 0.18 \\
\hline Textiles & & & -0.0872 & 0.9 \\
\hline Other & & & -0.4651 & $35.96 * * *$ \\
\hline -Log likelihood & \multicolumn{2}{|c|}{$1380.17^{* * *}$} & \multicolumn{2}{|c|}{$1407.7 * * *$} \\
\hline $\begin{array}{l}\text {-Full log likelihood } \\
\mathrm{N}=1004\end{array}$ & \multirow{2}{*}{\multicolumn{2}{|c|}{$2185.94 * * *$}} & \multirow{2}{*}{\multicolumn{2}{|c|}{$2158.4 * * *$}} \\
\hline $\mathrm{N}=1004$ & & & & \\
\hline
\end{tabular}

$*=$ Significant at the 5 percent level.

$* *$ = Significant at the 1 percent level.

*** = Significant below 1 percent level.

Notes: The excluded variable for marital status is unmarried, and for industry the excluded category comprises exhibits that are in "untraditional" fields for women, such as engines, transportation, chemicals, and heavy industries. A five-year patent is a cheaper patent that expires at the end of five years.

Sources: Institut national de propriete industrielle; France, Ministère de l'agriculture (various years).

the values for women who were (or had been) married, relative to the excluded variable, single women. The coefficients for the interaction between marital status and manufacturing suggest that wives or widows associated with manufacturing firms were significantly more likely to have made larger investments in patented inventions. This finding is consistent with the idea that patenting by women was enhanced by their participation in family firms.

\section{PATTERNS OF ENTREPRENEURSHIP AND INNOVATION}

The patent records provided ample evidence of women who paid the significant fees required to secure property rights, many of whom were doing so in order to promote innovation in family firms that they 
co-owned and managed. As in other countries, during this era women in France were unable to acquire managerial or innovative human capital through formal schooling or external apprenticeships, but family firms offered an environment that could compensate for external institutional disadvantages. If women were active participants in the business, especially while their male relatives were alive, then transitions to their leadership would be less disruptive and greater longevity of family firms would be more likely.

The patent records offered quantitative evidence of a complex process in which women negotiated institutional disabilities and transactions costs but ultimately prevailed in part because of the net advantages offered by family firms. Patents, however, are characterized by a number of drawbacks that imply they offer an imperfect index of both invention and innovation. In particular, not all inventions are patented or patentable, many patents are never renewed past the first term, and their market and technical value varies significantly (Griliches 1990). Such issues are compounded under a registration system with high fees, where the filter for patentability is wealth rather than the technical merit of the invention. From an economic perspective, value is added when the patented discovery benefits consumers either indirectly through increased productivity of inputs, or directly in the form of lower prices, or new and improved final goods.

Arguably the most important aspect of entrepreneurial activity is the final step of commercialization and successful market placement of products, and patent records do not shed much light on this process. A sceptic might thus question the representativeness of evidence drawn from patent records. One way to address such concerns is to examine a different source of information. This section analyzes women's participation in commercialization through their involvement in national exhibitions in France. Such systematic data, unlike the patent statistics, are a direct means to make visible the business activities of women over time, in a highly competitive environment. Moreover, the detailed reports from the individual exhibitions offer unique qualitative information on the role of women in the operation of family firms.

The French Exhibitions of National Industry were intended to provide a stimulus to domestic production and industrialization and were the inspiration for subsequent international expositions such as the Paris Universal Exposition of 1855. As Table 4 illustrates, these events expanded in scope and objectives between 1798 and 1849. The roster of exhibitors, size of the display space, and the number of prizes offered increased steadily over this period, as did the popularity of the event with attendees and 
TABLE 4

EXHIBITORS AND AWARDS AT THE FRENCH EXPOSITIONS, 1798-1855

\begin{tabular}{lcccccc}
\hline \hline & & \multicolumn{2}{c}{ Total Awards } & & \multicolumn{2}{c}{ Women } \\
\cline { 3 - 4 } \cline { 6 - 7 } Year & $\begin{array}{c}\text { Total No. } \\
\text { Exhibitors }\end{array}$ & $\begin{array}{c}\text { Number } \\
\text { of Medals }\end{array}$ & $\begin{array}{c}\text { Number } \\
\text { of Awards }\end{array}$ & & $\begin{array}{c}\text { Percent } \\
\text { Medals }\end{array}$ & $\begin{array}{c}\text { Percent } \\
\text { Awards }\end{array}$ \\
\hline 1798 & 110 & 3 & 23 & & 33.3 & 4.4 \\
1801 & 220 & 34 & 80 & & 0.0 & 2.5 \\
1802 & 540 & 42 & 254 & & 9.5 & 1.6 \\
1806 & 1,422 & 131 & 610 & & 4.6 & 2.9 \\
1819 & 1,662 & 308 & 869 & & 4.2 & 2.6 \\
1823 & 1,648 & 475 & 1,091 & & 4.8 & 3.9 \\
1827 & 1,795 & 425 & 1,254 & & 4.7 & 3.4 \\
1834 & 2,447 & 708 & 1,785 & & 3.0 & 2.7 \\
1839 & 3,381 & 868 & 2,305 & & 2.5 & 2.2 \\
1844 & 3,958 & 1,277 & 3,253 & & 3.4 & 1.3 \\
1849 & 4,650 & 1,652 & 3,738 & & 3.1 & 2.9 \\
Total & 21,833 & 5,923 & 15,262 & & 3.4 & 2.5 \\
$1855^{*}$ & $10,731^{*}$ & 6,564 & 10,564 & & 1.0 & 0.8 \\
\hline
\end{tabular}

Notes: The total number of awards and exhibitors includes both men and women. Total awards comprise medals (gold, silver, and bronze) and citations or honourable mentions. The percentage shows the number of awards to women as a fraction of the total granted to all exhibitors in that year. *The total number of exhibitors for the 1855 Universal Exposition was 21,779, of which 10,731 were from France and its colonies.

Sources: Rapport du jury central (various years); Catalogue de l'Exposition Universelle (1856).

the general public. Displays at exhibitions provided advertising for the efforts of producers and firms before the age of mass marketing, and likely attracted custom from other tradesmen as well as from consumers. Increases in the number of awards per exhibitor are evident, and by the end of the period more than 80 percent of the entries would receive a medal or honourable mention. The proportion of accolades bestowed on women fell over time, although their propensity to get medals was higher than the propensity to obtain simple mentions, suggesting a higher average quality for female contributions.

Table 5 shows the patterns of female participation in the exhibitions in terms of marital status. The vast majority of awards that both men and women received at the industrial exhibitions went to businesses and, in particular, to manufacturers. It is useful to compare the statistics here with the patent records, and to note that women's efforts at exhibitions were directed, to an even greater extent than their patenting, towards production and commercialization. Among patent holders, 47.4 percent 
TABLE 5

WOMEN'S PARTICIPATION IN INDUSTRIAL EXPOSITIONS, BY MARITAL STATUS, $1791-1855$

\begin{tabular}{|c|c|c|c|c|}
\hline & $\begin{array}{c}\text { Single } \\
\text { (Percent) }\end{array}$ & $\begin{array}{l}\text { Widow } \\
\text { (Percent) }\end{array}$ & $\begin{array}{c}\text { Married } \\
\text { (Percent) }\end{array}$ & $\begin{array}{c}\text { Total } \\
\text { (Percent) }\end{array}$ \\
\hline \multicolumn{5}{|l|}{ Industry } \\
\hline Apparel & 28.2 & 11.9 & 29.9 & 20.5 \\
\hline Arts & 16.4 & 16.3 & 14.5 & 14.5 \\
\hline Corsets & 4.5 & 1.1 & 12.2 & 5.4 \\
\hline Food & 2.7 & 4.7 & 1.8 & 3.3 \\
\hline Household & 19.1 & 12.6 & 15.8 & 14.1 \\
\hline Nontraditional & 3.6 & 18.1 & 9.5 & 11.6 \\
\hline Textiles & 25.5 & 33.2 & 14.5 & 28.7 \\
\hline Misc & 1 & 2.3 & 1.8 & 1.6 \\
\hline \multicolumn{5}{|l|}{ Occupation } \\
\hline Artisan & 17.4 & 7.7 & 16.7 & 12.2 \\
\hline Businesswoman & 2.2 & 7.1 & 8.8 & 6.9 \\
\hline Corset-maker & 6.5 & 0.6 & 9.6 & 5 \\
\hline Manufacturer & 73.9 & 78.9 & 57.9 & 70.5 \\
\hline Other & 0 & 5.8 & 7 & 3.5 \\
\hline \multicolumn{5}{|l|}{ Time } \\
\hline $1791-1834$ & 34.6 & 30 & 31.2 & 29.5 \\
\hline $1835-1844$ & 13.6 & 17.3 & 14 & 14.6 \\
\hline $1845-1850$ & 20 & 14.8 & 22.6 & 17.5 \\
\hline $1851-1855$ & 31.8 & 37.9 & 32.1 & 38.4 \\
\hline \multicolumn{5}{|l|}{ Awards } \\
\hline None & 34.6 & 32.5 & 35.3 & 37.4 \\
\hline One & 38.2 & 29.6 & 40.3 & 33.3 \\
\hline Two & 15.4 & 19.9 & 17.6 & 17.2 \\
\hline More than two & 11.8 & 18.1 & 6.8 & 12.1 \\
\hline Collaborators & 27.3 & 31.8 & 11.3 & 22.3 \\
\hline Patentee & 17.3 & 20.1 & 22.7 & 19.3 \\
\hline Paris Residency & 59.1 & 51 & 67.2 & 54.8 \\
\hline Total & 17.1 & 43.0 & 34.3 & $\mathrm{~N}=645$ \\
\hline
\end{tabular}

Notes: The table shows column percentages for 645 observations; totals may not sum to 100 because of missing values. The data include all women who obtained at least an honourable mention by the juries for the expositions. "Nontraditional" fields for women comprise engines, transportation, chemicals, and heavy industries. Patent holders were determined by matching the names of exhibitors to the records of the Institut national de propriété industrielle.

Sources: Rapport du jury central (various years); Catalogue de l'Exposition Universelle (1856).

were in manufacturing, compared to 70.5 percent of those who received some form of mention at the industrial fairs. The percentage of married women in manufacturing firms or with another person (collaborators) was somewhat lower, in part because family firms would typically have 
been listed under the husband's name. We know this was indeed often the case because women's subsequent "emergence" in the records as widows makes their previous efforts as wives more visible. Widows, who inherited businesses that had been founded or managed by their husbands, tended to be the least likely to offer exhibits in the realm of traditionally female industries such as apparel and household items; by contrast, 18.1 percent of their awards were in technical fields, and one-third were in the textile industry.

It is useful to analyze the factors that influenced persistence, or continued recognition for industrial excellence among women entrepreneurs in these Exhibitions (see Table 6). Each award was unique to a recipient for any specific year, so their frequency count indicates the degree of persistence over time in the quality of innovations. A few single women were in business with relatives, but in general marriage and widowhood show a stronger relationship with family firms ${ }^{43}$ More than 34 percent of awards accrued to married women, and a further 40 percent of awards went to widows, a large number of whom were representing firms in which they had been active prior to the husband/father's death. ${ }^{44}$ Manufacturing firms that were associated with married women and widows were significantly likely to receive greater numbers of awards, suggesting that such family firms were continuing to participate at a high level in the national exhibitions over the course of several years. Regressions with interactions for patentee status (not reported) support the view that such women were also more involved in sustained investments in commercialization as patent holders.

Some of the reports reveal more systematic research and development among multiple award winners. A combination of scientific expertise and entrepreneurial acumen is rare in any era, but we can point to at least two such examples among French women. Marguerite-Marie Degrand

${ }^{43}$ The Henriot Brother, Sister \& Company from Reims made flannel and fleece textiles that juries at various exhibitions regarded as consistently of a superb quality. Their products received numerous accolades and medals, including a coveted gold medal at the Paris Expositions of 1827 and 1834, which were awarded to the son and his widowed mother. The firm of Lespermont Brothers \& Sister manufactured paper and they jointly obtained a patent for a machine press that was more economical.

${ }^{44}$ Numerous examples of women actively engaging in innovations that built on their husbands' success are visible in the reports of the juries for expositions. Ferdinand Ladrière obtained a silver medal in 1819 for the production of high-quality fabrics. After he died, Mme Veuve Ladrière took over, and under her management the factory at Aisne employed 1,500 workers. The jury at the next exhibition in 1823 bestowed a rare gold medal on her products, noting that she had made "remarkable progress." The jury similarly remarked on the great improvements Mme Veuve Decoudun and her foreman had made to boilers for public laundries. She had not only maintained the worthy reputation that her husband had acquired, she had surpassed his achievements and her innovations in 1849 comprised the biggest advance in the industry so far. 
TABLE 6

BINOMIAL REGRESSIONS OF FEMALE PARTICIPATION IN INDUSTRIAL EXPOSITIONS, 1791-1855 DEPENDENT VARIABLE: NUMBER OF TIMES AWARDS GRANTED

(1)

\begin{tabular}{|c|c|c|c|c|}
\hline & & & \\
\hline & Coeff. & Wald Chi-sq & Coeff. & Wald Chi-sq \\
\hline Intercept & 53.11 & $91.87 * * *$ & 53.6514 & $96.09 * * *$ \\
\hline Paris residence & 0.14 & $2.68^{*}$ & 0.0817 & 0.83 \\
\hline Year & -0.03 & $92.50 * * *$ & -0.0292 & $95.74 * * *$ \\
\hline Wife/widow & -0.04 & 0.1 & -0.1373 & 1.16 \\
\hline Mfg firm owned by wife/widow & 0.72 & $54.59 * * *$ & 0.7294 & $56.11 * * *$ \\
\hline \multicolumn{5}{|l|}{ Industry } \\
\hline Apparel & & & -0.3729 & $8.97 * * *$ \\
\hline Food & & & 0.3595 & 2.53 \\
\hline Household & & & -0.1831 & 1.62 \\
\hline Textiles & & & -0.2196 & $3.13^{*}$ \\
\hline Other & & & 0.0081 & 0.0 \\
\hline Patent holder & & & 0.5069 & $30.99 * * *$ \\
\hline -Log likelihood & \multicolumn{2}{|c|}{$457.4 * * *$} & \multicolumn{2}{|c|}{$428.8 * * *$} \\
\hline -Full log likelihood & \multicolumn{2}{|c|}{$736.7 * * *$} & \multicolumn{2}{|c|}{$706.8 * * *$} \\
\hline & \multicolumn{2}{|c|}{$\mathrm{N}=645$} & \multicolumn{2}{|c|}{$\mathrm{N}=645$} \\
\hline
\end{tabular}

* = Significant at the 5 percent level.

** = Significant at the 1 percent level.

*** = Significant below 1 percent level.

Notes: The data include all women who obtained at least an honourable mention by the juries for the expositions. The excluded variable for marital status is unmarried. The excluded variable for industry comprises the "nontraditional" fields, such as engines, transportation, chemicals, and heavy industries. Patent holders were determined by matching the names of exhibitors to the records of the Institut national de propriété industrielle.

Sources: Rapport du jury central (various years); Catalogue de l'Exposition Universelle (1856).

made valuable contributions to scientific and industrial advance, through research findings associated with the international quest to replicate crucible steel from Damascus (Daumalin and Tachoire 2007) ${ }^{45}$ Elisabeth Gervais was also renowned because of her research and development into

45 The renowned English chemist, Michael Faraday, and his collaborator James Stoddart published their discoveries on steel alloys in 1820 , but their claim to priority was contested by the French authorities because of the efforts of Mme Marguerite-Marie Degrand and her husband. Mme Degrand received a honourable mention for her stainless steel cutlery at the exposition of 1819, and a medal in 1823 for her contributions to the art of making metal products that rivaled those of Damascus. The Society for the Encouragement of National Industry bestowed on her its Grand Medal, and in 1824 she was one of its rare female members. 
oenology, which resulted in two patents in 1818 and 1820 for apparatuses to condense the vapours in winemaking. She opened one company in Paris to market the patent rights for specific districts, and a second in Montpellier that was under the management of her brother. Despite the quibbling among contemporary scientists about the originality and value of the Gervais invention, the sale of these rights to practicing winemakers earned her significant profits.

These data offer unique insights into the experience of entrepreneurs who demonstrated exceptional initiative and business acumen. One of these, Mary Louise Sensitive Armfield (1793-1871), was the daughter of Thomas Armfield, a manufacturer who immigrated to France from Birmingham, and established a textile spinning factory, Toiles de Mayenne, in the Indre-Loire region in 1806. Mary married her father's business partner in 1814, and participated in the running of the business. Some sources claim that she did so only after being widowed; however, the exhibition evidence clearly identifies her as the responsible party well before this period. On the death of her husband in 1828, she took sole control of the company and managed it for more than four decades until the age of 68. The firm grew rapidly, introduced mechanical steamdriven processes, and was able to produce high-quality products in large quantities at competitive prices. Toiles de Mayenne was technologically innovative, and earned silver medals at the Exposition of French Industry in 1823 and 1827, which the judges opined were "distinctions that were well-deserved." These merits were sustained, and 30 years later accolades were still being bestowed.

Toiles de Mayenne also illustrates the importance of nontechnological innovations in the success of business enterprises, and in particular the introduction of "family-friendly" management practices that improved the conditions of the labour force. The company operated on a scale that was unusual at the time, and employed hundreds of (primarily women) workers (760 in 1812). During Mary Armfield's tenure, the firm established free accommodations for workers in an autonomous village; each family was assigned two private rooms, a garden, and a communal room to share with other workers. The company also owned a farm that produced fresh healthy food for the employees, and the workers' children were freely educated at a company school, with the hours corresponding to those of the factory. A contemporary guide to the district (Reichard 1827, p. 168) noted that Mme Armfield's factory was "a source of good, not only for the owner, but for the entire population." 


\section{CONCLUSION}

The French economy has generally been faulted for its relative delay in industrialization, which some have linked to cultural attitudes, too great a dependence on family firms, and to obstacles that hampered women's integration into the market economy. At the same time, as Goldin (1986) noted, the subject of women in the market remains a "mystery," and that assessment is especially true of female business participation in nineteenth-century Europe. Although "much can be learned by taking seriously the "family' part of 'family firms" (Bertrand and Schoar 2006, p. 95), the interactions among such institutions as the family, relational connections, and other forms of social capital, and women's participation in risk-taking and technological innovation, are clearly complex and difficult to systematically evaluate and elucidate. The analytical challenges are exacerbated by a lack of historical information on the internal structure of firms and their managers, especially when those managers included wives, daughters, or widows.

This article sheds light on these debates by employing unique sources of information drawn from patent records and the annals of industrial exhibitions in France. Such information is clearly not representative of all female market participants, who typically would have been sole proprietors or partners in small-scale endeavours related to their skills at sewing or other household tasks. These "penny capitalists" may have been disadvantaged by the very mechanisms and processes that facilitated the economic contributions of many of the women in these records, and an examination of the nature and effect of inequalities of wealth and class among women in French business remains an important area for future research. However, these data are valuable because they allow us to investigate the validity of the claim that entrepreneurial women were unique or rare exceptions in nineteenth-century France, and to relate their activities to institutional variables. These women, now made more visible, introduced innovations, took risks, were active in commercialization and competition, and managed large-scale enterprises, often with hundreds of employees and significant capitalization. Their experience allows us to draw more general inferences regarding the role of women and family institutions in entrepreneurship and in economic development. In particular, the results from this study suggest that family firms can offer a conduit for the skills and abilities of individuals who are relatively disadvantaged members of society.

Social and economic progress are promoted by flexible rules and standards, and by institutions that can adjust to compensate for drawbacks in other realms of society. As in many other countries, married women 
in France were burdened by cultural norms and expectations, as well as laws that restricted their capacity to engage in contracts, hold property, or prosecute claims in court, on their own account. At the same time, women were not as likely to acquire human capital or business training from formal schooling and outside apprenticeships, and were limited in their ability to mobilize capital in financial markets. Such exclusionary practices and disabilities provided manifest obstacles for women who wished to participate in the marketplace on their own accord. Under these circumstances, family businesses permitted some women a wider sphere of economic activities and influence than they could otherwise have attained. As such, the prevalence of family firms rather than corporations need not signal "retardation" or failure to adjust to the needs of a market economy. Instead, different forms of business organization might offer appropriate solutions to the specific circumstances and needs of each society.

\section{REFERENCES}

Arbour, Roméo. Dictionnaire des femmes libraires en France, 1470-1870. Paris: Librairie Droz, 2003.

Barker, Hannah. The Business of Women: Female Enterprise and Urban Development in Northern England, 1760-1830. New York: Oxford University Press, 2006.

Beachy, Robert, Beatrice Craig, and Alastair Owens, eds. Women, Business and Finance in Nineteenth-Century Europe: Rethinking Separate Spheres. Oxford and New York: Berg, 2006.

Beattie, Cordelia, and Matthew Frank Stevens (eds). Married Women and the Law in Premodern Northwest Europe. Woodbridge: Boydell Press, 2013.

Benoit, Serge et al. (eds). Encourager l'innovation en France et en Europe. Paris: CTHS, 2007.

Bertrand, Marianne, and Antoinette Schoar. "The Role of Family in Family Firms." Journal of Economic Perspectives 20, no. 2 (2006): 73-96.

Bessière, Céline. "Female and Male Domestic Partners in Wine-Grape Farms (Cognac, France): Conjugal Asymmetry and Gender Discrimination in Family Businesses." History of the Family 19, no. 3 (2014): 341-57.

Blanc, Étienne. Traité de la contrefaçon en tous genres et de sa poursuite en justice. Paris: H. Plon, 1855.

Boudjaaba, Fabrice (ed). Le travail et la famille en milieu rural, XVIe-XXIe siècle. Rennes: Presses Universitaires de Rennes, 2014.

Bressolles, Paul. De la femme du commerçant : examen critique de la jurisprudence. Paris: Rousseau, 1888.

Bridel, Louis Adolphe. Le mouvement féministe et le droit des femmes. Geneva: Ch. Eggimann \& Cie., 1893.

Carlos, Ann M., and Larry Neal. "Women Investors in Early Capital Markets, 1720 1725." Financial History Review 11, no. 2 (2004): 197-224.

-. "The Micro-Foundations of the Early London Capital Market: Bank of England Shareholders During and After the South Sea Bubble, 1720-25." Economic History Review (New Series) 59, no. 3 (2006): 498-538. 
Carter, Edward et al. (editors). Enterprise and Entrepreneurs in Nineteenth- and Twentieth-Century France. Baltimore: Johns Hopkins University Press, 1976.

Catalogue Officiel. Exposition des Produits de L'industrie de Toutes les Nations, 1855. Paris: E. Panis, 1856.

Catalogues des Expositions des produits de l'industrie française. Rapport du jury central. Paris: Bouchard-Huzard, various years.

Chandler, Alfred D. Scale and Scope: Dynamics of Industrial Capitalism. Cambridge: Harvard University Press, 1994.

Chanteux, Anne. «Les inventives. Femmes, inventions et brevets en France à la fin du XIXe siècle.» Documents pour l'histoire des techniques 17, décembre (2009): 90-97.

Craig, Beatrice. "Petites Bourgeoises and Penny Capitalists: Women in Retail in the Lille Area During the Nineteenth Century." Enterprise and Society 2, no. 2 (2001): $198-224$.

Crossick, Geoffrey, and Heinz-Gerhard Haupt. The Petite Bourgeoisie in Europe 1780 1914: Enterprise, Family and Independence. New York: Routledge, 1995.

Crowston, Clare Haru. Fabricating Women: The Seamstresses of Old Regime France, 1675-1791. Durham, NC: Duke University Press, 2001.

Cucculelli, Marco, and Giacinto Micucci. "Family Succession and Firm Performance: Evidence from Italian Family Firms." Journal of Corporate Finance 14, no. 1 (2008): 17-31.

Daubié, Julie V. La femme pauvre au XIXe siècle: Ouvrage couronné par l'Académie de Lyon. Lyon: Guillaumin et Cie., 1866.

Daumalin, Xavier, and Henri Tachoire. "Un couple d'innovateurs marseillais et la Société d'encouragement pour l'industrie nationale: les époux Degrand-Gurgey." In Encourage l'innovation en France et en Europe, edited by Serge Benoit et al., 123-40. Paris: CTHS, 2007.

Delphy, Christine, and Diana Leonard. Familiar Exploitation: A New Analysis of Marriage in Contemporary Western Societies. Cambridge, MA: Polity Press, 1992.

de Neuville, A. "Le genie de l'invention chez les femmes." La Revue mondiale: ancienne Revue des revues 32, no. 1 (1900): 184-91.

Desan, Suzanne, and Jeffrey Merrick. Family, Gender, and Law in Early Modern France. University Park: Penn State Press, 2010.

Destable, M. De l'évolution féministe comparée en France et en Amerique. Rouen: LeCerf, 1899.

de Vries, Jan. "The Industrious Revolution and Economic Growth, 1650- 1830." In The Economic Future in Historical Perspective, edited by Paul A. David and Mark Thomas, 43-71. Oxford and New York: Oxford University Press, 2003.

Federico, Pasquale J. "Historical Patent Statistics 1791-1961." Journal of the Patent Office Society 46, no. 2 (1964): S. 89-171.

Foreman-Peck, James, Elisa Boccaletti, and Tom Nicholas. "Entrepreneurs and Business Performance in Nineteenth Century France." European Review of Economic History 2, no. 3 (1998): 235-62.

France. Bulletin des lois de la République française. Paris: 1'Imprimerie de la république, various years.

France, Ministère de l'agriculture. Catalogue des brevets d'invention, d'importation et de perfectionnement. Paris: Bouchard-Huzard, various years. 
Galvez-Behar, Gabriel. La République des inventeurs. Propriété et organisation de l'invention en France, 1791-1922. Rennes: Presses universitaires de Rennes, 2008. Gelbart, Nina R. The King's Midwife: A History and Mystery of Madame du Coudray. Berkeley, Calif: University of California Press, 1998.

Goldin, Claudia. "The Economic Status of Women in the Early Republic: Quantitative Evidence." Journal of Interdisciplinary History 16, no. 3 (1986): 375-404.

Grantham, George. "Occupational, Marital, and Life-Cycle Determinants of Women's Labor Force Participation in Mid-Nineteenth-Century Rural France." Feminist Economics 18, no. 4 (2012): 97-119.

Griliches, Zvi. "Patent Statistics as Economic Indicators: A Survey." Journal of Economic Literature 28, no. 4 (1990): 1661-707.

Hardwick, Julie. Family Business: Litigation and the Political Economies of Daily Life in Early Modern France. Oxford and New York: Oxford University Press, 2009.

_ . "Seeking Separations: Gender, Marriages, and Household Economies in Early Modern France." French Historical Studies 21, no. 1 (1998): 157-80.

Hilaire-Perez, Liliane. L'invention technique au siècle des Lumières. Paris: Albin Michel, 2000.

Hoffman, Philip T., Gilles Postel-Vinay, and Jean-Laurent Rosenthal. "Private Credit Markets in Paris, 1690-1840." Journal of Economic History 52, no. 2 (1992): 293-306.

- Priceless Markets: The Political Economy of Credit in Paris, 1660-1870. Chicago: University of Chicago Press, 2001.

Hong, Gong-Soong. "The Role of Wives in Family Businesses: The Paid and Unpaid Work of Women." Family Business Review 3, no. 2 (1990): 125-37.

Horrell, Sara, and Jane Humphries. "Women's Labour Force Participation and the Transition to the Male-Breadwinner Family, 1790-1865." Economic History Review 48, no. 1 (1995): 89-117.

James, Harold. Family Capitalism: Wendels, Haniels, Falcks, and the Continental European Model. Cambridge, MA: Harvard University Press, 2006.

Khan, B. Zorina. "Married Women's Property Laws and Female Commercial Activity: Evidence from United States Patent Records, 1790-1895." Journal of Economic History 56, no. 2 (1996): 356-88.

—. " 'Not for Ornament': Patenting Activity by Nineteenth-Century Women Inventors." Journal of Interdisciplinary History 31, no. 2 (2000): 159-95.

- The Democratization of Invention: Patents and Copyrights in American Economic Development. Cambridge and New York: NBER and Cambridge University Press, 2005.

- "Selling Ideas: An International Perspective on Patenting and Markets for Technology, 1790-1930." Business History Review 87, no. 1 (2013): 39-68.

_. "Related Investing: Corporate Ownership and the Dynamics of Capital Mobilization." Unpublished Working Paper, 2015.

Khan, B. Zorina, and Kenneth L. Sokoloff. " 'Schemes of Practical Utility': Entrepreneurship and Innovation among 'Great Inventors' During Early American Industrialization, 1790-1865.” Journal of Economic History 53, no. 2 (1993): 289-307.

- "Institutions and Democratic Invention in 19th Century America." American Economic Review 94, no. 2 (2004): 395-401. 
Labardin, Pierre, and Paulette Robic. "Epouses et petites entreprises." Revue Française de Gestion 38, no. 188 (2008): 97-117.

Lachat, Stéphanie. Les pionnières du temps: vies professionnelles et familiales des ouvrières de l'industrie horlogère suisse: 1870-1970. Neuchâtel: Alphil-Presses universitaires suisses, c2014.

Lamoreaux, Naomi. Insider Lending: Banks, Personal Connections, and Economic Development in Industrial New England. Cambridge and New York: Cambridge University Press, 1996.

Lamoreaux, Naomi R., and Kenneth L. Sokoloff. "Market Trade in Patents and the Rise of a Class of Specialized Inventors in the 19th-Century United States." American Economic Review 91, no. 2 (2001): 39-44.

Landes, David. The Unbound Prometheus: Technological Change and Industrial Development in Western Europe from 1750 to the Present. Cambridge and New York: Cambridge University Press, 1969.

Lanza, Janine Marie. From Wives to Widows in Early Modern Paris: Gender, Economy, and Law. Aldershot, England, and Burlington, VT: Ashgate, c2007.

Martinetti, Brice. Les négociants de La Rochelle au XVIIIe siècle. Rennes: Presses universitaires de Rennes, c2013.

McMillan, James F. France and Women, 1789-1914: Gender, Society and Politics. London: Routledge, 2000.

Nicholas, Tom. "Clogs to Clogs in Three Generations? Explaining Entrepreneurial Performance in Britain Since 1850." Journal of Economic History 59, no. 3 (1999): 688-713.

O'Brien, Patrick, and Caglar Keyder. Economic Growth in Britain and France 1780 1914: Two Paths to the Twentieth Century. London: Routledge, 2012.

Ogilvie, Sheilagh. A Bitter Living: Women, Markets, and Social Capital in Early Modern Germany. Oxford: Oxford University Press, 2003.

—. "How Does Social Capital Affect Women? Guilds and Communities in Early Modern Germany." American Historical Review 109, no. 2 (2004): 325-59.

Pagé, Camille. La coutellerie depuis l'origine jusqu'à nos jours: La fabrication de la coutellerie. Paris: H. Rivière, 1898.

Pérez-González, Francisco. "Inherited Control and Firm Performance." American Economic Review 96, no. 5 (2006): 1559-88.

Perpigna, Antoine. Manuel des inventeurs et des brevetés (8e édition). Paris: A. Perpigna, 1852.

Phillips, Nicola J. Women in Business, 1700-1850. London: Boydell \& Brewer, 2006.

Pretel, David, and Saiz, Patricio. "Patent Agents in the European Periphery: Spain (1826-1902)." History of Technology (Series) 31 (2012): 97-114.

Redondi, Pietro. "Nation et Entreprise: la Société d'encouragement pour l'industrie nationale, 1801-1818." History and Technology (Series) 5 (1988): 193-222.

Reichard, Heinrich August Ottokar. Guide classique du voyageur en France, dans les Pays-Bas et en Hollande. Paris: Audin, 1827.

Renouard, Augustin-Charles. Traité des brevets d'invention (3e édition revue et augmentée). Paris: Guillaumin, 1865.

Richards, Sarah A. “The Development of Women's Economic Rights in 19th Century America: Legislative Influences and Economic Impacts." Honors Thesis. Brunswick, ME: Bowdoin College, 2010. 
Sicsic, Pierre. "City-Farm Wage Gaps in Late Nineteenth-Century France." Journal of Economic History 52, no. 3 (1992): 675-95.

Smith, Michael S. The Emergence of Modern Business Enterprise in France, 1800 1930. Cambridge: Harvard University Press, 2006.

Thompson, Victoria. The Virtuous Marketplace: Women and Men, Money and Politics in Paris, 1830-1870. Baltimore: Johns Hopkins, 2000.

United States Patent Office. Annual Report of the Commissioner of Patents. Washington, DC: GPO, various years.

Vallier, Ernest. Le fondement du droit successoral en droit français. Paris: Larose, 1903.

Viret, Jérôme-Luther. Le sol et le sang: la famille et la reproduction sociale en France, du Moyen Âge au XIXe siècle. Paris : CNRS, 2014.

Voltaire (François-Marie Arouet). Dictionnaire philosophique, tome 4, article « Femme. » Paris: éd. Lequien, 1829.

Wang, Calvin. "Daughter Exclusion in Family Business Succession: A Review of the Literature." Journal of Family and Economic Issues 31, no. 4 (2010): 475-84.

Watherston, Edward James. The Industrial Employment of Women in France Compared with England. London: Spottiswoode, c.1879. 